Original Article

\title{
Genetic variations among the isolates of Bipolaris Maydis based on phenotypic and molecular markers
}

\author{
Variações genéticas entre os isolados de Bipolaris Maydis podem ser baseadas em \\ marcadores fenotípicos e moleculares
}

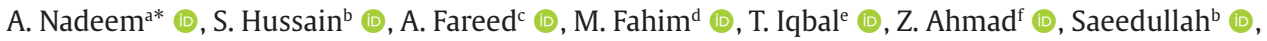 \\ R. Karims and A. Akbar ${ }^{\text {h }}$ (D) \\ aThe University of Agriculture Peshawar, Department of Plant Pathology, Amir Muhammad Khan Campus, Mardan, Pakistan

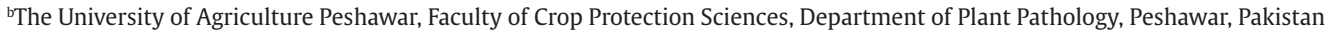 \\ 'The University of Agriculture Peshawar, Institute of Biotechnology \& Genetic Engineering, Peshawar, Pakistan \\ dIslamia College University, Peshawar, Pakistan \\ 'The University of Agriculture Peshawar, Faculty of Crop Protection Sciences, Department of Entomolgy, Peshawar, Pakistan \\ ${ }^{\mathrm{f}}$ Adaptive Research Program, Quetta, Baluchistan \\ 'The University of Agriculture Peshawar, Department of Agricultural and Applied Economics, Amir Muhammad Khan Campus, Mardan, Pakistan \\ hational Agricultural Research Centre, Crop Diseases Research Institute, Islamabad, Pakistan
}

\begin{abstract}
Maydis leaf blight, caused by Bipolaris maydis, is an important disease of maize crop in Khyber Pakhtunkhwa (KP) Pakistan. Fifteen isolates of the pathogen, collected across KP, were studied for variability based on phenotypic and molecular markers. Significant variability among the isolates was observed when assessed using phenotypic traits such as radial growth, spore concentration, fungicide sensitivity and virulence. The isolates were classified into six culture groups based on colour, texture and margins of the colony. Conidial morphology was also variable. These were either straight or slightly curved and light to dark brown in colour. Fungicide test showed significant variation in the degree of sensitivity against Carbendazim. Isolate Bm8 exhibited maximum radial growth on carbendazim spiked plates. Conversely, isolate Bm15 showed the lowest radial growth. Variations in virulence pattern of the isolates were evident when a susceptible maize variety Azam was inoculated with spores of $B$. maydis. Genetic variability amongst the isolates was also estimated by RAPD as well as sequencing of ITS region. The RAPD dendrogram grouped all the isolates into two major clusters. Average genetic distance ranged from $0.6 \%$ to $100 \%$, indicating a diverse genetic gap among the isolates. Maximum genetic distance was found between isolates $\mathrm{Bm} 9$ and $\mathrm{Bm} 10$ as well as Bm2 and Bm8. Conversely, isolates $\mathrm{Bm} 13$ and $\mathrm{Bm} 15$ were at minimum genetic distance. Phylogenetic dendrogram based on sequencing of ITS region grouped all the isolates into a single major cluster. The clusters in both the dendrogram neither correlate to the geographical distribution nor to the morphological characteristics.
\end{abstract}

Keywords: Bipolaris maydis, genetic variations, ITS, maydis leaf blight, RAPD.

\begin{abstract}
Resumo
A ferrugem das folhas de maydis, causada por Bipolaris maydis, é uma doença importante da cultura do milho em Khyber Pakhtunkhwa (KP), Paquistão. Quinze isolados do patógeno, coletados em KP, foram estudados quanto à variabilidade com base em marcadores fenotípicos e moleculares. Variabilidade significativa entre os isolados foi observada quando avaliada por meio de características fenotípicas, como crescimento radial, concentração de esporos, sensibilidade a fungicida e virulência. Os isolados foram classificados em seis grupos de cultura com base na cor, textura e margens da colônia. A morfologia dos conídios também foi variável. Estes eram retos ou ligeiramente curvos e de cor marrom-claro a escuro. $O$ teste de fungicida mostrou variação significativa no grau de sensibilidade ao carbendazim. $\mathrm{O}$ isolado $\mathrm{Bm} 8$ exibiu crescimento radial máximo em placas com adição de carbendazim. Por outro lado, o isolado Bm15 apresentou o menor crescimento radial. As variações no padrão de virulência dos isolados foram evidentes quando uma variedade de milho suscetível Azam foi inoculada com esporos de B. maydis. A variabilidade genética entre os isolados também foi estimada por RAPD, bem como sequenciamento da região ITS. O dendrograma RAPD agrupou todos os isolados em dois grupos principais. A distância genética média variou de $0,6 \%$ a $100 \%$, indicando uma lacuna genética diversa entre os isolados. A distância genética máxima foi encontrada entre os isolados Bm9 e Bm10 e também entre Bm2 e Bm8. Por outro lado, os isolados Bm13 e Bm15 estavam a uma distância genética mínima. $O$ dendrograma filogenético baseado no sequenciamento da região ITS
\end{abstract}

*e-mail: azranadeem@aup.edu.pk

Received: June 10, 2021 - Accepted: August 23, 2021

This is an Open Access article distributed under the terms of the Creative Commons Attribution License, which permits unrestricted use, distribution, and reproduction in any medium, provided the original work is properly cited. 
agrupou todos os isolados em um único aglomerado principal. Os agrupamentos em ambos os dendrogramas não se correlacionam com a distribuição geográfica nem com as características morfológicas.

Palavras-chave: Bipolaris maydis, variações genéticas, ESTÁ, ferrugem das folhas de maydis, RAPD.

\section{Introduction}

Maydis leaf blight (MLB)), caused by Bipolaris maydis (Telomorph: Cochliobolus heterostrophus), is an important disease of maize throughout the world. The disease has a great historical background due to its epidemic in the United States of America (USA) in 1970, causing losses of one billion dollar in that year alone (Manamgoda et al., 2011). Recently, prevalence of the disease has been documented from tropical and subtropical maize growing regions of the world with warm and humid weather (Alim Shah et al., 2007; Martinez et al., 2010). Pakistan, India, Bangladesh, Nepal, Philippines, Indonesia, Japan, China, Taiwan, Thailand and Vietnam have been mostly affected by the disease (Ali and Yan, 2012).

Bipolaris maydis has a morphological and physiological variability due to multinucleate mycelium and conidia with subsequent heterokaryosis (Chand et al., 2003). Existence of variability in this pathogen has been reported previously (Karimi, 2003) which is of significant importance. For understanding the co-evolution of pathogen in plant pathosystem, the estimation of genetic variability is necessary (Milgroom et al., 1992). The pathogen may evolve to break down the host resistance. Further, it can also adapt itself to changes in climatic conditions, crop practices and fungicides (Stanković et al., 2007). Similarly, in plant-pathogen interactions, plants need to be sturdy enough to cope with the ever changing pathogen. To test the resistance level of different genotypes, these must be tested against diverse population of the pathogen (Pal et al., 2015). Monitoring and constant surveillance of the pathogen divergence is therefore important in this scenario (Gafur et al., 2002).
Initially, cultural, morphological (Lakshmi, 1984), physiological (Pal et al., 2015) and toxicological (Lixin et al., 2011 ) based variations were used to document variability of a pathogen. In recent years, molecular tools have also been used in the study of variability. Such tools have provided a framework to understand the taxonomy and population structure of the pathogen. The use of DNA profile system reveals variation in nucleotide sequence of DNA. A number of molecular marker systems have been developed and utilized for characterization of plant pathogens. These markers include Restriction Fragment Length Polymorphism (RFLP) (Milgroom et al., 1992), Randomly Amplified Polymorphic DNA (RAPD) (Peever and Milgroom, 1994) and Amplified Fragment Length Polymorphism (AFLP) (Mueller et al., 1996).

The present study was therefore, carried out to estimate genetic variability among the isolates of Bipolaris maydis collected from diverse geographical regions of Khyber Pakhtunkhwa (KP) - Pakistan based on phenotypic and molecular markers.

\section{Materials and Methods}

\subsection{Isolation and identification of Bipolaris maydis from infected leaves}

Fifteen isolates of Bipolaris maydis collected from diverse geographical regions of KP (Table 1) were selected for estimation of genetic variability. The infected leaves with characteristic disease symptoms were washed thoroughly under tap water. Approximately $5 \mathrm{~mm}^{2}$ sized pieces from

Table 1. Isolates of Bipolaris maydis collected from different districts of Khyber Pakhtunkhwa province

\begin{tabular}{|c|c|c|c|c|c|c|}
\hline Isolates & $\begin{array}{c}\text { GenBank Accession } \\
\text { Numbers }\end{array}$ & Sites & District & Elevation (m) & $\mathbf{N}$ & $\mathbf{E}$ \\
\hline $\mathrm{Bm} 1$ & MN783607 & Warsak & Peshawar & 382 & $33^{\circ} 57.534$ & $071^{\circ} 31.082$ \\
\hline $\mathrm{Bm} 2$ & MN783608 & Pandu & Peshawar & 316 & $33^{\circ} 59.716$ & $071^{\circ} 36.523$ \\
\hline $\mathrm{Bm} 3$ & MN783609 & Shahbaz gari & Mardan & 305 & $34^{\circ} 13.580$ & $072^{\circ} 09.800$ \\
\hline $\mathrm{Bm} 4$ & MN783610 & Bhala gari & Mardan & 307 & $34^{\circ} 13.588$ & $072^{\circ} 07.295$ \\
\hline $\mathrm{Bm} 5$ & MN783611 & Azakhel & Nowshera & 285 & $34^{\circ} 00.161$ & $071^{\circ} 52.850$ \\
\hline $\mathrm{Bm} 6$ & MN783612 & Pirsabak & Nowshera & 288 & $34^{\circ} 03.447$ & $072^{\circ} 01.661$ \\
\hline $\mathrm{Bm} 7$ & MN783613 & Shoulgara & Charsadda & 287 & $34^{\circ} 08.799$ & $071^{\circ} 42.752$ \\
\hline $\mathrm{Bm} 8$ & MN783614 & Shahmansoor & Swabi & 314 & $34^{\circ} 04.072$ & $072^{\circ} 26.557$ \\
\hline $\mathrm{Bm} 9$ & MN783615 & Central swabi & Swabi & 328 & $34^{\circ} 06.275$ & $072^{\circ} 27 . .882$ \\
\hline Bm10 & MN783616 & Central charsadda & Charsadda & 293 & $34^{\circ} 09.688$ & $071^{\circ} 44.932$ \\
\hline $\mathrm{Bm} 11$ & MN783617 & Nesata & Charsadda & 302 & $34^{\circ} 11.049$ & $071^{\circ} 46.804$ \\
\hline $\mathrm{Bm} 12$ & MN783618 & Dargai & Charsadda & 304 & $34^{\circ} 10.599$ & $071^{\circ} 52.114$ \\
\hline Bm13 & MN783619 & Laachi & Kohat & 610 & $33^{\circ} 364.0608$ & $071^{\circ} 2641.2$ \\
\hline Bm14 & MN783620 & Mung & Haripur & 588 & $33^{\circ} 59.9982$ & $072^{\circ} 56.0454$ \\
\hline $\mathrm{Bm} 15$ & MN783621 & Khan pur & Haripur & 550 & $33^{\circ} 10.168$ & $072^{\circ} 13.221$ \\
\hline
\end{tabular}


infected leaves were cut and disinfected using $0.1 \%$ mercuric chloride solution for $30 \mathrm{sec}$ followed by rinsing in sterilized distilled water. To isolate the pathogen, the excised pieces were placed on Potato Dextrose Agar (PDA) medium in petri plates and incubated at $25^{\circ} \mathrm{C}$ for 3-7 days. Fungal colonies were characterized and grouped, based on their morphological features as described by Manamgoda et al. (2014) and Marin-Felix et al. (2017).

\subsection{Cultural and morphological variability among the isolates of Bipolaris maydis}

Cultural and morphological variability within these isolates was determined by culturing each isolate of $B$. maydis on PDA medium for 10 days at $25^{\circ} \mathrm{C}$ in a Completely Randomized Design (CRD) with three replications.

Data on fungal radial growth was recorded after seven days of incubation while colony colour, texture and growth pattern were recorded 10 days after incubation. Fungal radial growth was measured from the underside of the petri plates with the help of a measuring scale. Measurement was made along two perpendicular lines and their mean was recorded.

Conidial concentration $\mathrm{ml}^{-1}$ was determined using a haemocytometer, after immersing $15 \mathrm{~mm}$ discs of 10 days old pure cultures of each isolate in $50 \mathrm{ml}$ sterilized water and filtering the suspension through double layered muslin cloth. An aliquot of 10 microliter of homogenous spore suspension was transferred to the haemocytometer slide with the help of a pippete tip and number of conidia was counted. Data on colour and septation of conidia were also recorded.

\subsection{Virulence of the isolates of Bipolaris maydis}

The isolates were tested for their virulence on a susceptible maize cultivar (Azam) under screen house conditions. The experiment was laid out as randomized complete block design (RCBD) with four replications. For each isolate, four pots $(30 \mathrm{~cm})$ were filled with $2 \mathrm{~kg}$ sterilized soil mix. Inoculum of each isolate was prepared by dipping $15 \mathrm{~mm}$ discs of the pure culture in $50 \mathrm{ml}$ sterilized distilled water, filtering the suspension in double layered muslin cloth and determining the spore concentration with the help of haemocytometer. Finally, spore concentration of the inoculum was adjusted to $2 \times 10^{4} \mathrm{ml}^{-1}$. Each pot initially contained four plants which were eventually thinned to two plants per pot after emergence. Inoculum $(5 \mathrm{ml})$ was applied to fourth leaf of two weeks old seedling in each pot.

Plants were covered with polyethylene bags for one week to maintain sufficient humidity. Inoculation was done twice at eight-day interval. Disease severity data were recorded after 20 days of inoculation according to a disease severity scale (Sharma 1983). To ascertain the most aggressive isolate, virulence pattern of all isolates was determined by categorizing the disease severity response of diseased plants into least virulent (LV), moderately virulent (MV) and highly virulent (HV) (Pal et al., 2015).

\subsection{Fungicide sensitivity of the isolates of Bipolaris maydis}

A completely randomized experiment with three replicates was designed to determine the fungicide sensitivity of the isolates in vitro. A fungicide Schencard (a.i; Carbendazim) was selected for the assay. Fungicide concentration was adjusted as $300 \mathrm{ppm}$. The fungicide was incorporated into PDA medium after sterilization before dispensing in petri dishes under aseptic conditions. Plates without fungicide served as control. A $5 \mathrm{~mm}^{2}$ plug of each isolate was placed at the center of petri dishes under aseptic conditions. The plates were sealed with parafilm and incubated at $25^{\circ} \mathrm{C}$. Data on colony diameter were measured after 10 days of incubation.

Data regarding radial growth, spore concentration, number of septa per spore, fungicide sensitivity and aggressiveness were statistically analyzed using statistix 8.1 software. For comparing means, least significant difference (LSD) test was applied wherever significant differences were observed among the means.

\subsection{Cluster analysis}

Dendrogram based on phenotypic data including radial growth, spore concentration, number of septa, fungicide sensitivity and aggressiveness was constructed using statistical package IBM SPSS Statistic 20 through hierarchical cluster analysis.

\subsection{DNA extraction from Bipolaris maydis isolates}

DNA of 15 isolates of Bipolaris maydis was extracted by culturing the single spore of the pathogen on potato dexrtrose broth (PDB). The broth was autoclaved in 500 $\mathrm{ml}$ flask for $15-20$ minutes at $121^{\circ} \mathrm{C}$. Mycelial $\left(1 \mathrm{~cm}^{2}\right)$ disk of the fungus, excised from the margins of fresh culture, was placed in each flask. The flasks were incubated for one week at $28^{\circ} \mathrm{C}$ in a shaker incubator with continuous shaking. The suspended mycelium was filtered through sterilized filter paper (Whatmann No 1) using a vacuum pump.

DNA was extracted according to Raeder and Broda (1985) with some modifications. Autoclaved, pre chilled mortar and pestle was used to homogenize $200 \mathrm{mg}$ mycelium in liquid Nitrogen. The homogenized powdered mycelium was suspended in 600ul of DNA extraction buffer (Tris HCL 50mM, pH 8, EDTA $125 \mathrm{mM} \mathrm{pH} \mathrm{8,} \mathrm{NaCl}$ $50 \mathrm{mM}$, marcaptaethanol 0.1\% (v/v) and (w/v) Sodium -NLauryl Sarcosinate). The suspension was deproteineized with 300ul each of Tris saturated phenol and chloroform isoamyl alcohol (24:1), followed by centrifugation for $5 \mathrm{~min}$ at $15,000 \mathrm{rpm}$. The supernatant was transferred to another tube and a subsequent extraction was done with chloroform isoamyl alcohol (24:1). An aliquot of precipitated sodium acetate and ethanol was added to the aqueous phase and stored at $-80^{\circ} \mathrm{C}$ for $10 \mathrm{~min}$. The frozen aqueous phase was centrifuged at $15,000 \mathrm{rpm}$ for 10 min washed with ice chilled ethanol (70\%), air dried and centrifuged at 12,000 rpm for $5 \mathrm{~min}$. Finally, DNA was suspended in TE buffer and stored at $-20^{\circ} \mathrm{C}$ for further use.

\subsection{Randomly Amplified Polymorphic DNA (RAPD) assay}

Amplification of genomic DNA of the selected isolates of $B$. maydis was performed through RAPD-PCR, using a set of arbitrary primers (Table 2) with the following conditions. A reaction volume $25 \mathrm{ul}$ was prepared with 
Table 2. Arbitrary primers used for RAPD-PCR to determine population structure of Bipolaris maydis in Khyber Pakhtunkhwa.

\begin{tabular}{cccc}
\hline Primer & Sequence & $\begin{array}{c}\text { Product } \\
\text { size }(\mathbf{b p})\end{array}$ & $\begin{array}{c}\text { Annealing } \\
\text { temperature }\left({ }^{\circ} \mathbf{C}\right)\end{array}$ \\
\hline OPF-1 & ACGGATCCTG & 10 & 34.2 \\
OPI-2 & GGAGGAGAGG & 10 & 34.7 \\
OPI-7 & CAGCGACAAG & 10 & 34.4 \\
OPI-9 & TGGAGAGCAG & 10 & 34.0 \\
OPL-8 & AGCAGGTGGA & 10 & 36.9 \\
OPF-9 & CCAAGCTTCC & 10 & 33.2 \\
OPA-1 & CAGGCCCTTC & 10 & 37.8 \\
OPA-3 & AGTCAGCCAC & 10 & 35.2 \\
\hline
\end{tabular}

crude template DNA (1ul), $25 \mathrm{mM} \mathrm{MgCl}_{2}$ (2ul), $10 \mathrm{mM}$ dNTPs mix (0.4ul), primer (2ul), 5 Unit Taq polymerase (0.5) and $10 \mathrm{x}$ PCR buffers (2ul). PCR was performed with the following standardized temperature profile: initial denaturation at $94^{\circ} \mathrm{C}$ for $2 \mathrm{~min}$, followed by 45 cycles of denaturation at $92^{\circ} \mathrm{C}$ for $1 \mathrm{~min}$ and annealing at $37^{\circ} \mathrm{C}$ for 1 min, elongation period of $2 \mathrm{~min}$ at $72^{\circ} \mathrm{C}$ and final extension period for $5 \mathrm{~min}$ at $72^{\circ} \mathrm{C}$. The amplification products were electrophoresed on $2 \%$ agarose/TBE gel and visualized by staining with ethidium bromide under ultra violet light and then photographed.

The RAPD pattern of each isolate was evaluated. Each amplification product was considered as RAPD marker and recorded across all samples by assigning binary values. The bands that could be reproduced in the gel were denoted with a value 1 while the absence of a band at the same locus was assigned a 0 value. Data were compiled using a matrix in which all observed bands or characters were listed. Bi-variate analysis was then performed using a computer program "Popgene" 32 version 1.31 to generate dissimilarity matrix.

\subsection{Sequencing of ITS region of Bipolaris maydis}

Amplification of ITS region of rDNA of the selected isolates was performed through PCR with species specific primer pair JB587 (5/CAGTTGCAATCAGCGTCAGTA3/)/JB596 (3'GAGGTCAAAAGTTAAAAATCGTAA5') designed from ITS region between $18 \mathrm{~S}$ and $25 \mathrm{~S}$ ribosomal DNA subunits (Beck, 1998). PCR was carried out in 50ul reaction volume. Each reaction had a 25ul Dream Taq green PCR master mix, 2.5ul each of forward and reverse primers, 5ul DNA and 15ul deionized water. Temperature profile for PCR was adjusted with initial denaturation at $94^{\circ} \mathrm{C}$ for $3 \mathrm{~min}$ followed by 40 cycles with denaturation at $94^{\circ} \mathrm{C}$ for $30 \mathrm{~S}$, annealing at $58^{\circ} \mathrm{C}$ for $30 \mathrm{~S}$, extension at $72^{\circ} \mathrm{C}$ for $1 \mathrm{~min}$ and final extension at $72^{\circ} \mathrm{C}$ for $5 \mathrm{~min}$. Finally, the amplified PCR products were run on $1 \%$ agarose/TBE gel and visualized with ethidium bromide under UV light. Purification and sequencing of the amplification product was performed with forward primer JB587 by Worldwide Scientific, Pakistan.

The sequences of all isolates in the study were blast searched using BLASTn (Basic Local Alignment Search Tool) at National Centre for Biotechnology Information (NCBI) (http://www.ncbi.nlm.nih.gov/) database. Alignments of all sequences were made using Clustal O. Ambiguous regions and terminal gaps were delimited manually and excluded from the alignment wherever necessary (Katoh and Standley, 2013). Finally, the sequences were submitted to GenBank and accession numbers were allotted (Table 1).

The evolutionary history was inferred by using the Maximum likelihood method based on the Tamura-Nei model (Tamura and Nei, 1993). The tree with the highest log likelihood (-768.28) was constructed. The percentage of trees in which the associated taxa clustered together is shown next to the branches. Initial tree(s) for the heuristic search were obtained automatically by applying NeighborJoin and BioNJ algorithms to a matrix of pair wise distances estimated using the Maximum Composite Likelihood (MCL) approach, and then selecting the topology with superior log likelihood value. The tree was drawn to scale, with branch lengths measured in the number of substitutions per site. The analysis involved 15 nucleotide sequences. Codon positions included were $1 \mathrm{st}+2 \mathrm{nd}+3 \mathrm{rd}+$ Noncoding. All positions containing gaps and missing data were eliminated. There were a total of 330 positions in the final data set. Evolutionary analyses were conducted in MEGA7 (Kumar et al., 2016) with 1000 .

\section{Results}

\subsection{Genetic variability of Bipolaris maydis based on phenotypic markers}

\subsection{Cultural variability}

The isolates in general exhibited the following cultural characteristics after ten days of incubation at $25^{\circ} \mathrm{C}$ on potato dextrose agar medium. Mycelium was grayish white in colour initially but turning grayish black at maturity, extensive conidiophores arising singly or in small groups, straight or flexuous, septate, simple or branched and brown in colour. Conidia were light to dark brown, short or long, straight or slightly curved, septate and smooth (Figure 1).

Majority of the isolates were grayish black, however their texture and margins were variable. The colonies of the isolates $\mathrm{Bm} 1$ and $\mathrm{Bm} 4$ were grayish black with rough texture and irregular margins. Isolates Bm8, Bm14 and $\mathrm{Bm} 15$, although belonged to the same colour group, had a smooth texture with regular margins. Similarly, isolates Bm3, Bm9, Bm11, Bm12 and Bm13 were grayish black, smooth textured with irregular margins.

The remaining isolates were categorized as greenish black with variable texture and margins. Isolates $\mathrm{Bm} 2$, $\mathrm{Bm} 5$ and Bm10 were greenish black with rough texture and irregular margins. Similarly, isolate Bm7 was greenish black, smooth textured with regular margins. Isolate Bm6 was greenish black, smooth textured with irregular margins.

Conidia of the isolates $\mathrm{Bm} 3, \mathrm{Bm} 4, \mathrm{Bm} 7 \mathrm{and} \mathrm{Bm} 13$ were dark brown in color while those of the remaining isolates were light brown. Similarly, conidia of the isolates Bm2, $\mathrm{Bm} 3, \mathrm{Bm} 4, \mathrm{Bm} 7, \mathrm{Bm} 8, \mathrm{Bm} 9$ and $\mathrm{Bm} 13$ were slightly curved as opposed to the remaining isolates which produced straight conidia.

The isolates showed significant differences $(p<0.01)$ with regard to radial growth in $\mathrm{cm}$. Maximum radial growth $(6.23 \mathrm{~cm})$ was recorded for the isolate $\mathrm{Bm} 8$ followed by 

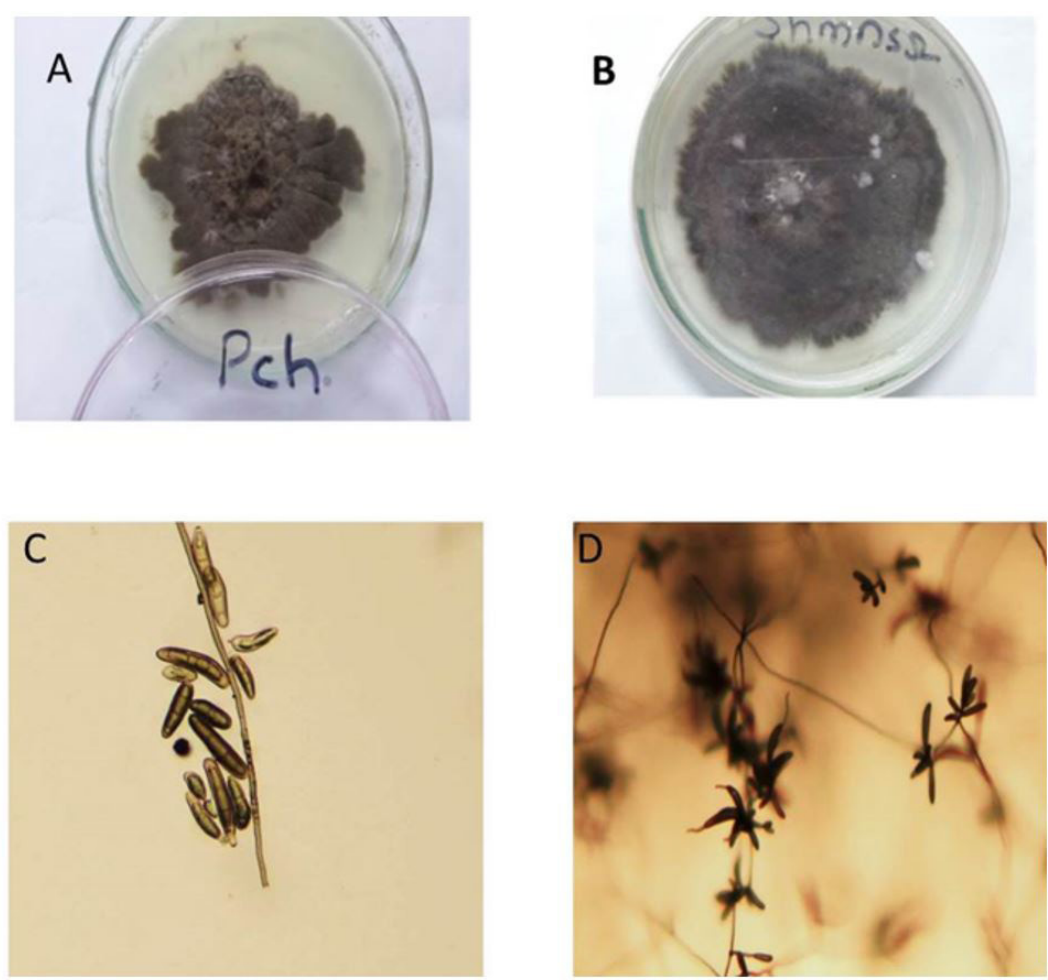

Figure 1. Colony, conidia and conidiophores of Bipolaris maydis, cultured on PDA medium. The pathogen was isolated from maize leaves infected with southern corn leaf blight.

isolate $\mathrm{Bm} 2(6.10 \mathrm{~cm})$ which were statistically at par with each other. The least radial growth $(2.51 \mathrm{~cm})$ was observed for the isolate $\mathrm{Bm} 1$. This was closely followed by isolate $\operatorname{Bm} 11(2.66 \mathrm{~cm}), \operatorname{Bm} 5(2.73 \mathrm{~cm})$ and $\operatorname{Bm} 14(2.81 \mathrm{~cm})$, which were statistically similar with one another (Table 3 ).

Isolates collected across KP produced variable number of conidial septation. The differences were however, statistically non-significant. Significant differences $(\mathrm{p}<0.01)$ were recorded for conidial concentration among the isolates. The highest conidial concentration was recorded for isolate $\mathrm{Bm} 11\left(110.33 \times 10^{3} \mathrm{ml}^{-1}\right)$. Conversely, the lowest conidial concentration ( $36.66 \times 10^{3} \mathrm{ml}^{-1}$ ) was observed for the isolate $\mathrm{Bm} 15$. This was closely followed by isolate Bm8 (43.33x 10 $\left.0^{3} \mathrm{ml}^{-1}\right), B m 12$ (46.66 $10^{3} \mathrm{ml}^{-1}$ ) and Bm9 $\left(51.66 \times 10^{3} \mathrm{ml}^{-1}\right)$, which were statistically similar with one another (Table 3 )

\subsection{Aggressiveness of the isolates of $B$. maydis}

Significant differences $(\mathrm{p}<0.01)$ were observed among the fifteen isolates in terms of their aggressiveness when inoculated on a susceptible maize variety Azam (Table 3). Among all the isolates tested for their virulence, 26.66\% were Highly Virulent (HV), 66.66\% were Moderately Virulent (MV) and 6.66\% were Least Virulent (LV). Isolate $\mathrm{Bm} 5$ was the most aggressive with disease severity of 3.22 followed by isolate $\mathrm{Bm} 6$ (3.17), $\mathrm{Bm} 1$ (3.05) and $\mathrm{Bm} 12$ (3.02). These isolates were accordingly classified as Highly Virulent (HV). Conversely, the lowest disease severity (1.95) was recorded for isolate $\mathrm{Bm} 3$ and was accordingly termed as Least Virulent (LV). The remaining isolates were Moderately Virulent (MV).

\subsection{Fungicide sensitivity test}

Significant differences $(\mathrm{p}<0.01)$ were observed when isolates were assessed against a fungicide Schencard. Colony diameter of isolates grown on fungicide amended medium ranged from $1.58 \mathrm{~cm}-3.00 \mathrm{~cm}$ after 10 days of incubation (Table 3). Differences in degree of sensitivity ranging from 35.11-66.66\% were recorded among all the isolates. The highest radial growth $(3.00 \mathrm{~cm})$ was observed for isolate Bm8, followed by the isolate Bm14 $(2.95 \mathrm{~cm})$ which was $66.66 \%$ and $65.55 \%$ of the known standard respectively. These two isolates were however statistically at par with each other. Conversely, the lowest radial growth (1.58 $\mathrm{cm}$ ), which was $35.11 \%$ of known standard, was recorded for the isolate $\mathrm{Bm} 15$.

\subsection{Cluster analysis}

Agglomerative hierarchical cluster analysis was performed to determine relatedness of the isolates. A dendrogram was constructed based on phenotypic markers including radial growth, conidial concentration and septation, sensitivity to fungicide and aggressiveness of the isolates. Dendrogram revealed that the selected 15 isolates can be divided into two major clusters (Figure 2). The first major cluster had two sub-clusters. Isolates Bm3, $\mathrm{Bm} 5, \mathrm{Bm} 10, \mathrm{Bm} 4, \mathrm{Bm} 6, \mathrm{Bm} 2, \mathrm{Bm} 1, \mathrm{Bm} 14$ and $\mathrm{Bm} 7$ were included in the first sub-cluster. While, isolates Bm11 and Bm13 were clustered into the second sub-cluster. The 
Table 3. Characteristics of various isolates of Bipolaris maydis collected from various locations in Khyber Pakhtunkhwa, Pakistan.

\begin{tabular}{|c|c|c|c|c|c|c|c|}
\hline \multirow{2}{*}{ Isolates } & \multirow{2}{*}{$\begin{array}{l}\text { Radial } \\
\text { growth }(\mathbf{c m})\end{array}$} & \multirow{2}{*}{$\begin{array}{l}\text { Conidial } \\
\text { septation }\end{array}$} & \multirow{2}{*}{$\begin{array}{c}\text { Conidial } \\
{\text { conc } \mathrm{ml}^{-1}} \\
\text { (thousand) }\end{array}$} & \multicolumn{2}{|c|}{ Aggressiveness } & \multicolumn{2}{|c|}{$\begin{array}{c}\text { Fungicide sensitivity against } \\
\text { Carbendazim }\end{array}$} \\
\hline & & & & $\begin{array}{l}\text { Disease } \\
\text { severity }\end{array}$ & $\begin{array}{l}\text { Virulence } \\
\text { pattern }\end{array}$ & $\begin{array}{c}\text { Colony } \\
\text { diameter }\end{array}$ & $\begin{array}{c}\text { \% growth allowed in } \\
\text { comparison to control (\%) }\end{array}$ \\
\hline $\mathrm{Bm} 1$ & $2.51 \mathrm{~d}$ & 3 & 86.66 bc & $3.05 a b c$ & $\mathrm{HV}$ & $2.41 \mathrm{abcd}$ & 53.55 \\
\hline $\mathrm{Bm} 2$ & $6.10 \mathrm{a}$ & 2 & $80.00 \mathrm{c}$ & $2.20 \mathrm{fgh}$ & MV & 2.0 bcde & 44.44 \\
\hline $\mathrm{Bm} 3$ & $3.60 \mathrm{~cd}$ & 3 & $73.33 \mathrm{c}$ & $1.95 \mathrm{~h}$ & LV & 2.0 bcde & 44.44 \\
\hline $\mathrm{Bm} 4$ & $4.00 \mathrm{bcd}$ & 5 & $80.00 \mathrm{c}$ & 2.62 bcdef & MV & $2.38 \mathrm{abcd}$ & 52.88 \\
\hline Bm5 & $2.73 \mathrm{~d}$ & 3 & $73.33 \mathrm{c}$ & $3.22 \mathrm{a}$ & $\mathrm{HV}$ & $2.38 \mathrm{abcd}$ & 52.88 \\
\hline Bm6 & $3.16 \mathrm{~cd}$ & 2 & $80.00 \mathrm{c}$ & $3.17 \mathrm{ab}$ & $\mathrm{HV}$ & 1.78 cde & 39.55 \\
\hline $\mathrm{Bm} 7$ & $5.33 \mathrm{ab}$ & 4 & 86.66 bc & $2.5 \mathrm{cdefgh}$ & MV & $2.48 \mathrm{abc}$ & 55.11 \\
\hline Bm8 & $6.23 \mathrm{a}$ & 4 & $43.33 \mathrm{~d}$ & $2.05 \mathrm{gh}$ & MV & $3.00 \mathrm{a}$ & 66.66 \\
\hline $\mathrm{Bm} 9$ & $3.73 \mathrm{~cd}$ & 4 & $51.66 \mathrm{~d}$ & 2.42 efgh & MV & $2.71 \mathrm{ab}$ & 60.22 \\
\hline Bm10 & $4.44 \mathrm{bc}$ & 3 & $76.66 \mathrm{c}$ & $2.55 \mathrm{cdefg}$ & MV & 2.10 bcde & 46.66 \\
\hline Bm11 & $2.66 \mathrm{~d}$ & 4 & $110.33 \mathrm{a}$ & 2.87 abcde & MV & 1.78 cde & 39.55 \\
\hline Bm12 & $5.33 \mathrm{ab}$ & 3 & $46.66 \mathrm{~d}$ & $3.02 \mathrm{abcd}$ & $\mathrm{HV}$ & $1.71 \mathrm{de}$ & 38.00 \\
\hline $\mathrm{Bm} 13$ & $3.08 \mathrm{~cd}$ & 5 & $96.66 \mathrm{~b}$ & $2.22 \mathrm{fgh}$ & MV & 2.01 bcde & 44.66 \\
\hline Bm14 & $2.81 \mathrm{~d}$ & 4 & 86.66 bc & $2.17 \mathrm{fgh}$ & MV & $2.95 \mathrm{a}$ & 65.55 \\
\hline Bm15 & $3.58 \mathrm{~cd}$ & 4 & $36.66 \mathrm{~d}$ & $2.47 \mathrm{defg}$ & MV & $1.58 \mathrm{e}$ & 35.11 \\
\hline
\end{tabular}

LV: Least Virulent with disease severity $=\leq 2.0 ; \mathrm{MV}$ : Moderately Virulent with disease severity $=2.1-2.9 ; \mathrm{HV}$ : Highly Virulent with disease severity $=3.0-5.0$. Known standard (control) for fungicide sensitivity: 5 . Means followed by the different letters (abcdefgh) in the same column are significantly different from one another according to least significant difference (LSD) test

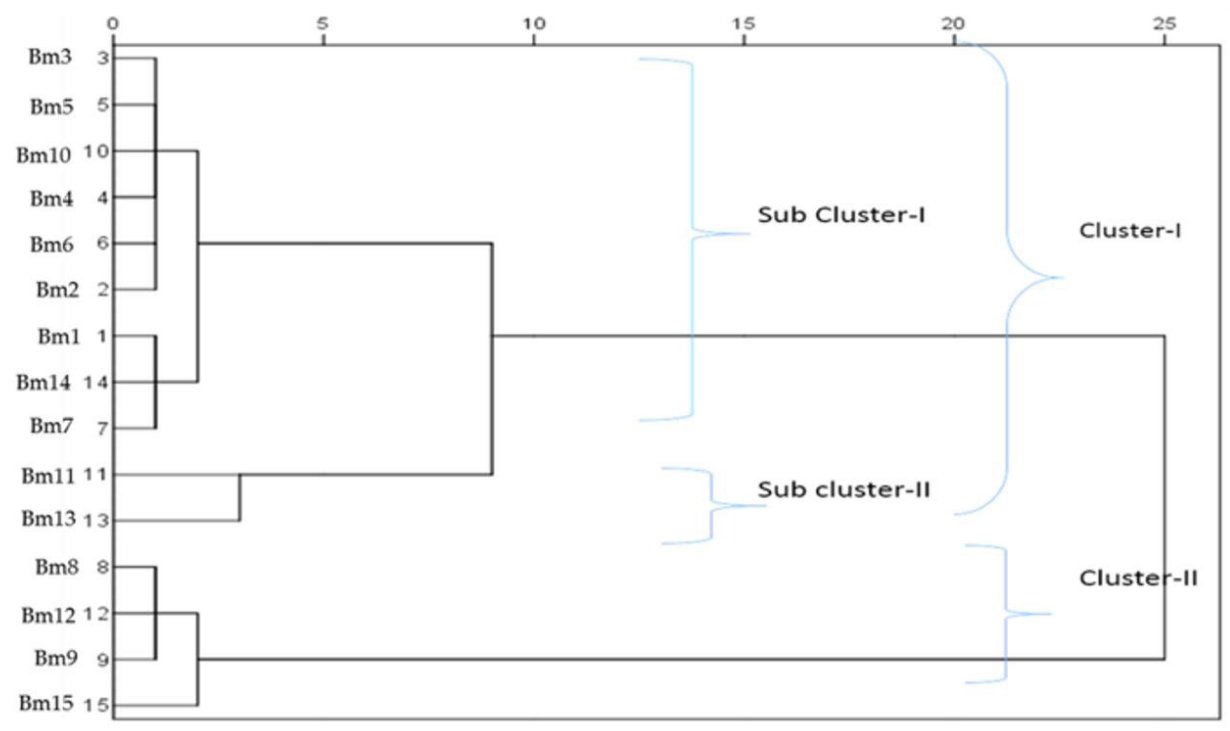

Figure 2. Agglomerative hierarchical clustering among 15 isolates of Bipolaris maydis based on phenotypic markers.

second major cluster included the isolates Bm8, Bm9, Bm12 and Bm15.

All the isolates in first sub-cluster were high to moderately virulent except isolate Bm3, which was least virulent. Similarly, moderate level of fungicide resistance and spore concentration amongst isolates was also recorded in this cluster. The second sub-cluster including isolates
Bm11 and Bm13 having maximum spore concentration than all other isolates, thus forming a single cluster. Both the isolates were slow growing and exhibited least resistance to the fungicide.

Isolates in the second major cluster (Cluster-II) had maximum colony diameter and minimum spore concentration; accordingly all were rated as moderately virulent, except 
isolate Bm9 which was highly virulent. Similarly, most of the isolates showed minimum fungicide resistance.

\subsection{Genetic variability based on RAPD marker}

Genetic variation was evident when polymorphic and reproducible bands were assessed for the isolates using RAPD marker (Figure 3). The genetic dissimilarity coefficient matrix of the 15 selected isolates of $B$. maydis based on eight RAPD primers was used to construct a dendogram by Unweighted Pair Group Method of Arithmetic Averages (UPGMA) function (Nei and Li, 1979), using the computer program "Popgene 32" version 1.31. The dendrogram classified the isolates into two major clusters. The first major cluster contained majority of the isolates, with two sub clusters (Figure 4). The first sub cluster contained the isolates $\mathrm{Bm} 1, \mathrm{Bm} 7, \mathrm{Bm} 11, \mathrm{Bm} 4$ and $\mathrm{Bm} 12$. The second sub cluster was made up of isolates Bm3, Bm14, Bm13, Bm15, $\mathrm{Bm} 10$ and $\mathrm{Bm} 8$. However, isolate $\mathrm{Bm} 8$ was different from rest of the isolates in the second sub cluster, although still remaining in the same sub cluster. The second major cluster including isolates $\mathrm{Bm} 2, \mathrm{Bm} 5, \mathrm{Bm} 6$ and $\mathrm{Bm} 9$ was relatively small. Isolate Bm9 seems to be the most dissimilar type from the rest of the isolates used during the analysis.

Average genetic distance was estimated between 0.6 to $100 \%$, indicating a wide range of genetic diversity among the isolates. Maximum pair wise genetic distance (100\%) was found between isolates $\mathrm{Bm} 9$ vs. $\mathrm{Bm} 10, \mathrm{Bm} 2$ vs. Bm8 closely followed by Bm9 and Bm15 (99.24\%), while the lowest genetic distance was found between isolates Bm13 and Bm15 (0.6\%), Bm3 vs. Bm14 (1.21\%) and Bm7 vs. Bm11 (4.48).

\subsection{Genetic variability based on sequencing ITS region}

Identity of 15 isolates of $B$. maydis was confirmed by sequencing the ITS region. BLASTn search was performed using nucleotide data base at NCBI (www.ncbi.nlm.nih. gov). The results revealed $98-100 \%$ identity of the isolates to other reported isolates of $B$. maydis in the database.

Evolutionary analysis of the ITS region grouped all the isolates into a single major cluster supported by bootstrap values (Figure 5). Two sub clusters of related isolates were also evident in the dendrogram. Sub cluster I (isolates Bm3, Bm5, Bm2, Bm9, Bm8, Bm1, Bm4 and Bm13) consisted of most of the isolates from the plains of KP including Peshawar, Nowshera, Mardan and Swabi. The second sub cluster (isolates Bm10, Bm14, Bm11, Bm12, Bm6, Bm7 and Bm15) included isolates from highlands of Haripur. However, all isolates of district Charsadda and one isolate of district Nowshera were also grouped in the same cluster. Isolate Bm15 clustered as an outlier.
$\begin{array}{llllllllllllllll}M & 1 & 2 & 3 & 4 & 5 & 6 & 7 & 8 & 9 & 10 & 11 & 12 & 13 & 14 & 15\end{array}$

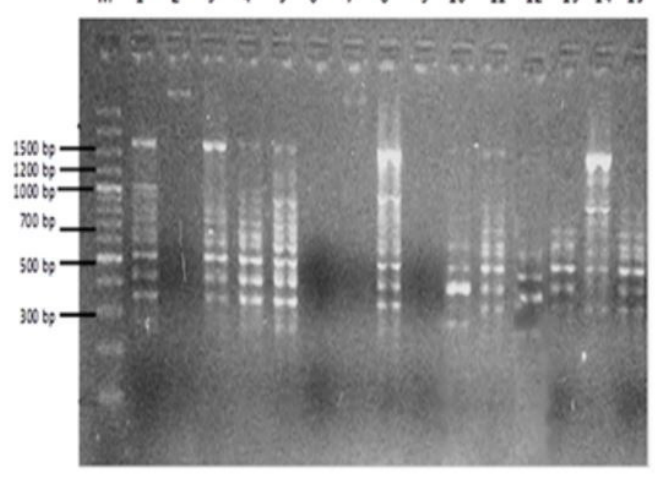

$\begin{array}{llllllllllllllll}M & 1 & 2 & 3 & 4 & 5 & 6 & 7 & 8 & 9 & 10 & 11 & 12 & 13 & 14 & 15\end{array}$

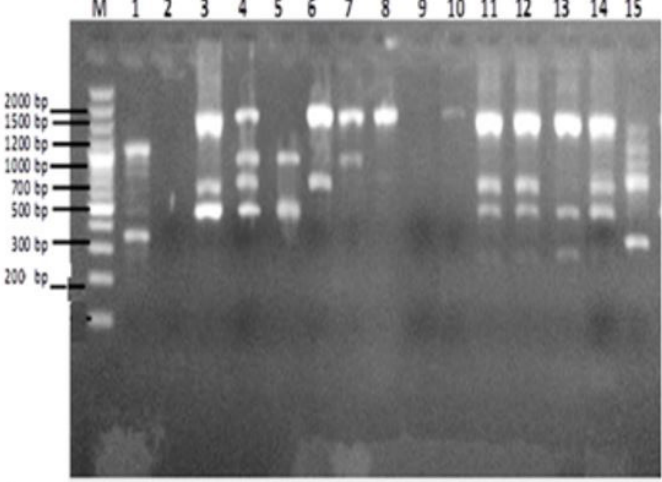

$\begin{array}{llllllllllllllll}M & 1 & 2 & 3 & 4 & 5 & 6 & 7 & 8 & 9 & 10 & 11 & 12 & 13 & 14 & 15\end{array}$
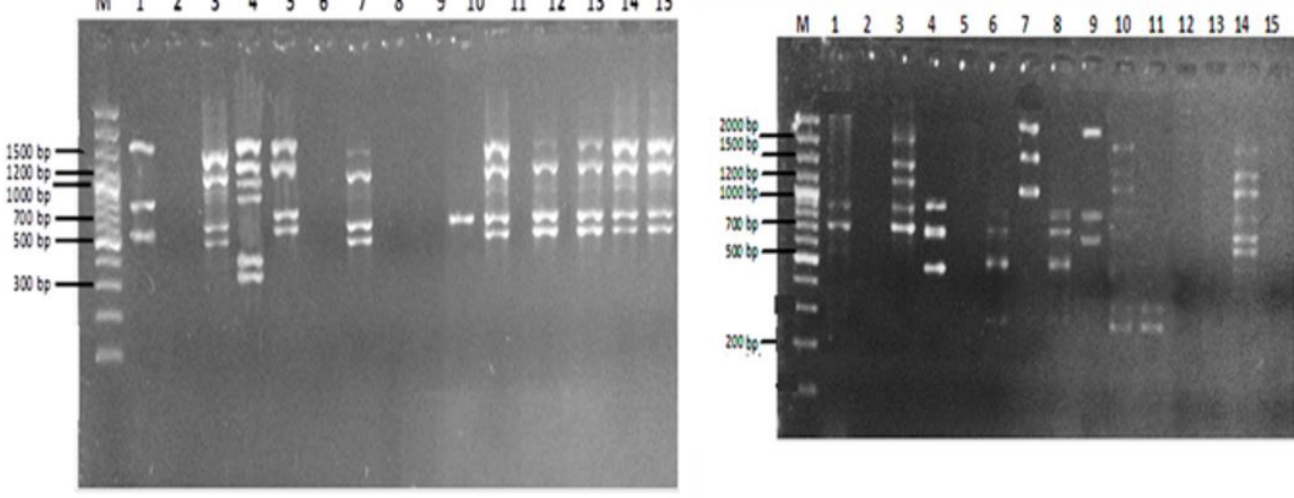

Figure 3. PCR based DNA profile of 15 isolates of Bipolaris maydis with different RAPD primers in agarose gel 2 (\%). Lane 1-15: isolates Bm1 to Bm15. M: 100 bp la. 


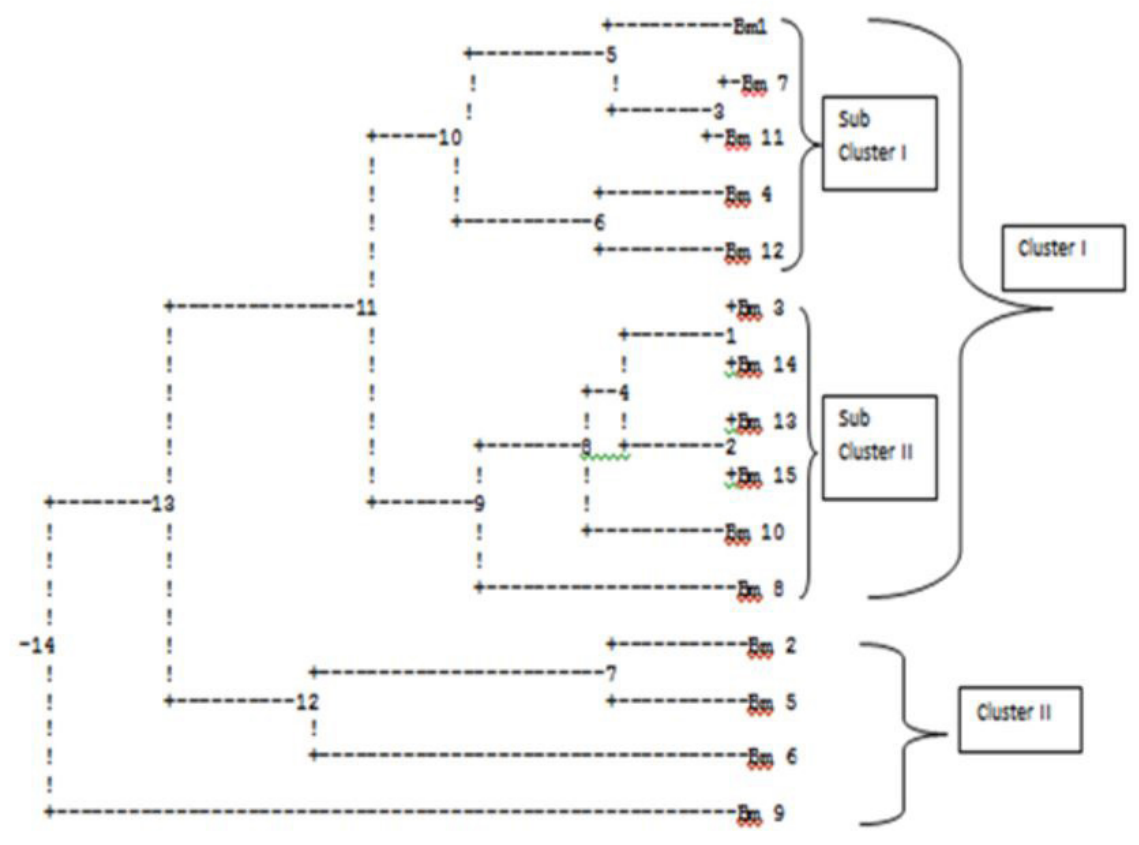

Figure 4. Dendrogram showing genetic distance among 15 isolates of Bipolaris maydis (Bm1-Bm15), using eight RAPD primers.

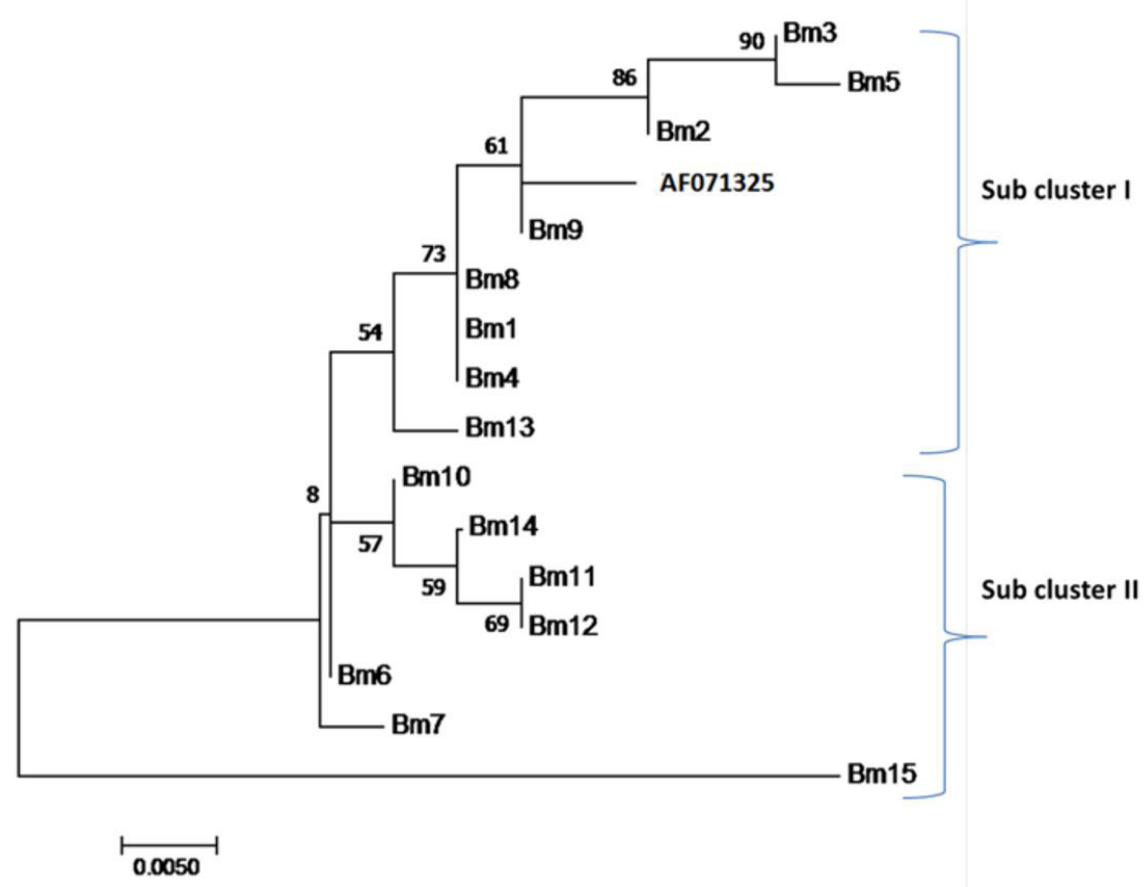

Figure 5. Dendrogram based on sequencing of ITS region aligned with reference sequence (AF071325) of Berbee et al. (1999), showing genetic distance among 15 isolates of Bipolaris maydis collected from various regions of Khyber Pakhtunkhwa during 2015.

\section{Discussion}

The isolates of Bipolaris maydis collected from different areas of the province were studied to determine variability in the pathogen population across KP. The morphological and cultural characters revealed that the isolates differed in colony and spore morphology. Similar variations in cultural and morphological characters of B. maydis have been reported previously (Oliveira et al., 1998; Gafur et al., 2002; Bhavani et al., 2016). Results of the present study confirmed that variability exists in the population structure 
of the pathogen and is suggestive of re-assortment of alleles and sexual recombination.

Differences were recorded in growth rate and sporulation of the isolates. Similar results were reported previously by Lakshmi (1984) and Reguchander et al. (1988). A negative correlation was found between radial growth and spore concentration of the isolates. Slow growing isolates were found to be profusely sporulating and vice versa. The results collaborate previous findings of Diaz and Bedendo (1999) where non sporulating isolates of $B$. oryzae were found to grow better than sporulating isolates of the pathogen.

The selection pressure applied by the frequent use of the fungicide increases the frequency of resistant isolates of $B$. maydis (Weems, 2016). Most of the isolates in the present study were insensitive to fungicide (Schencard) which is indicative of the indiscriminate use of the fungicide in the area. Availability of fungicides, high disease incidence in the previous years and inflated crop prices may have resulted in unabated use of fungicides (Wise and Mueller, 2011). Moreover, farmers practice reduced tillage which may help in increasing the buildup of the pathogen inoculum (Pedersen and Oldham, 1992). Although host resistance is a good option for disease control, virulent races of the pathogen overcome monogenic resistance while complete control of the disease is not possible with polygenic resistance (Ferguson and Carson, 2007). Therefore, fungicides have become a viable option for controlling the diseases (Mallowa et al., 2015). However, variations among the isolates based on fungicide insensitivity emphasize the need to revisit management strategies in future.

Variations among the isolates in terms of virulence were also evident as has been observed previously (Misra and Singh, 1972; Gopi, 2008; Akram and Singh, 2012 and Pal et al., 2015). It may be attributed to differences in genetic makeup of the isolates. Mono-culturing and repetitive use of available resistant cultivars may exert enough selection pressure on the pathogen thereby resulting in development of new virulent race (Nelson and Kline, 1969). Varieties with diverse genetic background in combination with other control measures should be adopted to overcome the virulence of the isolates in the area.

Clustering of the isolates based on colony and spore characteristics, fungicide insensitivity and aggressiveness reflected differences among the isolates. Isolates with similar characters tended to group together in one cluster. However, no clear cut grouping was evident among the isolates of nearby regions. Smaller sample size may well have been a confounding factor in inability of the phenotypic markers employed to determine relationship among the isolates. It is expected that analysis of a larger sample of isolates would provide detailed information on genetic variability of the pathogen.

Dendrogram based on RAPD marker classified all the isolates into two major clusters. Range of mean genetic distances estimated in isolates was 0.6 to $100 \%$. Afridi et al. (2011) also documented $100 \%$ genetic distance among the tea genotypes while using RAPD assay. Since isolates were collected from a diverse geographic region of KP in term of altitude and environmental conditions, the results suggest that these clusters have no clear cut correlation with geographical distribution as most of the isolates leaving aside $\mathrm{Bm} 2, \mathrm{Bm} 5, \mathrm{Bm} 6$ and $\mathrm{Bm} 9$ are clustered in a single major cluster. The observed deviation could be due to the migration of the pathogen across locations either through air or seed (Wetzel 3rd et al., 1999; Karwasra et al., 2002; Gopi 2008). Seed borne nature of the pathogen has been confirmed previously (Mishra et al., 1983; Kumar and Aggarwal, 1998). Similar observation on migration of the pathogen was also reported by Gopi (2008). Karimi (2003), however, did observe a strong correlation between geographical distribution and groups of the isolates of $B$. maydis when analyzed through RAPD. These results are in agreement with Fabre et al. (1995) who failed to establish correlation between polymorphic groups of the isolates of Colletotrichum lindemuthianum and their geographical origins. Weikert-Oliveira et al. (2002), Gogoi et al. (2014) and Karimishahari and Sharma (2016) also failed to produce conclusive evidence of a positive correlation between geographic variations and clustering of the isolates of $B$. maydis based on RAPD analysis.

Since, RAPD marker rarely give a reproducible picture of diversity within a specie in a small gerographical area, the isolates were subjected to ITS based fingerprinting. ITS-based genetic analysis revealed that all isolates clustered in a single major cluster. Since sub-clusters of related isolates were evident with an Outlier i.e., Isolate BM15; therefore, we believe that after introduction from the external source, the pathogen is established and is now evolving under the new geographical region (Gogoi et al., 2014). Although similarities among the isolates across the geographical locations were observed in general, yet a clear cut correlation was not evident as observed previously by Wang et al. (2017), using AFLP markers. We believe that a more detailed analysis using MLST-stratetgy or using more variable region would further decipher the genetic based diversity of the isolates.

\section{Acknowledgements}

The authors thank Higher Education Commission (HEC)Pakistan for providing financial support during the study.

\section{References}

AFRIDI, S.G., AHMAD, H., ALAM, M., KHAN, I.A. and HASSAN, M., 2011. DNA landmarks for genetic diversity assessment in tea genotypes using RAPD markers. African Journal of Biotechnology, vol. 10 , no. 69 , pp. 15477-15488. http://dx.doi.org/10.5897/ AJB11.801.

AKRAM, M. and SINGH, A., 2012. Variability and characterization of host response to Helminthosporium sativum, incitant of spot blotch of wheat. Indian Phytopathology, vol. 54, no. 4, pp. 429-434.

ALI, F. and YAN, J., 2012. Disease resistance in maize and the role of molecular breeding in defending against global threat. Journal of Integrative Plant Biology, vol. 54, no. 3, pp. 134-151. http:// dx.doi.org/10.1111/j.1744-7909.2012.01105.x. PMid:22333113.

ALIM SHAH, S., HIDAYAT-UR-RAHMAN., KHALIL, I.H. and IQBAL, M., 2007. Recurrent selection for maydis leaf blight resistance and grain yield improvement in maize. Pakistan Journal of 
Biological Sciences, vol. 10, no. 20, pp. 3632-3637. http://dx.doi. org/10.3923/pjbs.2007.3632.3637.

BECK, J.J. Detection of maize fungal pathogens using the polymerase chain reaction. USA. Industrial patent, no. 5,800,997. 1-9-1998.

BERBEE, M., PIRSEYEDI, M. and HUBBARD, S., 1999. Cochliobolus phylogenetics and the origin of known, highly virulent pathogens, inferred from ITS and glyceraldehyde-3-phosphate dehydrogenase gene sequences. Mycologia, pp. 964-977.

BHAVANI, T., GOHIL, V. and PATEL, J., 2016. Isolation, pathogenicity and culture media study of Helminthosporium maydis causing maydis leaf blight disease of maize. Advances in Life Sciences, vol. 5, pp. 77-80.

CHAND, R., PANDEY, S., SINGH, H., KUMAR, S. and JOSHI, A., 2003. Variability and its probable cause in natural populations of spot blotch pathogen Bipolaris sorokiniana of wheat (T. aestivum L.). Journal of Plant Diseases and Protection, vol. 110, no. 1, pp. 27-35.

DIAZ, C. and BEDENDO, I., 1999. Behaviour of sporulating and nonsporulating isolates of Helminthosporium oryzae in carbon and nitrogen sources and some amino acids. Fitopatologia Brasileira, vol. 24, no. 1, pp. 66-69.

FABRE, J., JULIEN, J., PARISOT, D. and DRON, M., 1995. Analysis of diverse isolates of Colletotrichum lindemuthianum infecting common bean using molecular markers. Mycological Research, vol. 99, no. 4, pp. 429-435. http://dx.doi.org/10.1016/S09537562(09)80640-0.

FERGUSON, L.M. and CARSON, M.L., 2007. Temporal variation in Setosphaeria turcica between 1974 and 1994 and origin of races 1, 23, and 23N in the United States. Phytopathology, vol. 97, no. 11, pp. 1501-1511. http://dx.doi.org/10.1094/PHYTO-97-11-1501. PMid:18943521.

GAFUR, A., MUJIM, S. and NUR AENY, T., 2002. Morphological and pathological variations in the Indonesian Cochliobolus heterostrophus (Pleosporaceae, Pleosporales, Euascomycetes). Pakistan Journal of Biological Sciences, vol. 5, no. 11, pp. 11951198. http://dx.doi.org/10.3923/pjbs.2002.1195.1198.

GOGOI, R., SINGH, S., SINGH, P.K., KULANTHAIVEL, S. and RAI, S., 2014. Genetic variability in the isolates of Bipolaris maydis causing maydis leaf blight of maize. African Journal of Agricultural Research, vol. 9, pp. 1906-1913.

GOPI, R., 2008. Pathogenic and molecular variability in Bipolaris maydis incitant of maydis leaf blight of maize. New Dehli: Krishikosh, an institutional repository of Indian national agricultural research system, 93 p. PhD thesis in Plant Pathology.

KARIMI, M.R. 2003. Investigations on genetics of disease resistance on Zea mays-Drechslera maydis pathosystem and variability in $D$. maydis. Indian Agricultural Research Institute; New Delhi. p 138.

KARIMISHAHARI, M.R. and SHARMA, R.C., 2016. Genetic variation among isolates of Bipolaris maydis using RAPD_PCR. Italian Journal of Mycology, vol. 45, pp. 19-28.

KARWASRA, S.S., MUKHERJEE, A.K., SWAIN, S.C., MOHAPATRA, T and SHARMA, R.P., 2002. Evaluation of RAPD, ISSR and AFLP markers for characterization of the loose smut fungus Ustilago tritici.J. Biochem. Biotechnology., vol. 11, no. 2, pp. 99-103. http:// dx.doi.org/10.1007/BF03263143.

KATOH, K. and STANDLEY, D.M., 2013. MAFFT multiple sequence alignment software version 7: improvements in performance and usability. Molecular Biology and Evolution, vol. 30, no. 4, pp. 772-780. http://dx.doi.org/10.1093/molbev/mst010. PMid:23329690.

KUMAR, M. and AGGARWAL, V.K., 1998. Location of seedborne fungi associated with discoulered maize seeds. Indian Phytopathology, vol. 51, no. 3, pp. 247-250.
KUMAR, S., STECHER, G. and TAMURA, K., 2016. Molecular evalutionary genetics analysis version 7.0 for bigger data sets. Molecular Biology and Evolution, vol. 33, no. 7, pp. 1870-1874. http://dx.doi.org/10.1093/molbev/msw054. PMid:27004904.

LAKSHMI, P., 1984. Differential interactions between Helminthosporium maydis Nisikado $\mathcal{E}$ Miyake incitant of maydis leaf blight and cultivars of Zea mays LM Sc.(Ag.). New Delhi: IARI, 60 p. MSc Thesis in Plant Pathology.

LIXIN, Z., JUN, Z. and JIANHUA, W., 2011. Sensitivity of Bipolaris maydis to five fungicides in Anhui Province. Plant Protection., vol. 37, no. 4, pp. 166-163.

MALLOWA, S.O., ESKER, V., PAUL, P.A., BRADLEY, C.A., CHAPARA, V.R., CONLEY, S.P. and ROBERTSON, A.E., 2015. Effect of maize hybrid and foliar fungicides on yield under low foliar disease severity conditions. Phytopathology, vol. 105, no. 8, pp. 1080-1089. http:// dx.doi.org/10.1094/PHYTO-08-14-0210-R. PMid:25760523.

MANAMGODA, D.S., CAI, L., BAHKALI, A.H., CHUKEATIROTE, E. and HYDE, K.D., 2011. Cochliobolus: an overview and current status of species. Fungal Diversity, vol. 51, no. 1, pp. 3-42. http://dx.doi. org/10.1007/s13225-011-0139-4.

MANAMGODA, D.S., ROSSMAN, A.Y., CASTLEBURY, L., CROUS, P.W., MADRID, H., CHUKEATIROTE, E. and HYDE, K.D., 2014. The genus Bipolaris. Studies in Mycology, vol. 79, pp. 221-288. http://dx.doi.org/10.1016/j.simyco.2014.10.002. PMid:25492990.

MARIN-FELIX, Y., GROENEWALD, J., CAI, L., CHEN, Q., MARINCOWITZ, S., BARNES, I., BENSCH, K., BRAUN, U., CAMPORESI, E., DAMM, U., DE BEER, Z.W., DISSANAYAKE, A., EDWARDS, J., GIRALDO, A., HERNÁNDEZ-RESTREPO, M., HYDE, K.D., JAYAWARDENA, R.S., LOMBARD, L., LUANGSA-ARD, J., MCTAGGART, A.R., ROSSMAN, A.Y., SANDOVAL-DENIS, M., SHEN, M., SHIVAS, R.G., TAN, Y.P., VAN DER LINDE, E.J., WINGFIELD, M.J., WOOD, A.R., ZHANG, J.Q., ZHANG, Y. and CROUS, P.W., 2017. Genera of phytopathogenic fungi: Gophy 1. St. Myc., vol. 86, pp. 99-216. http://dx.doi. org/10.1016/j.simyco.2017.04.002. PMid:28663602.

MARTINEZ, A., FRANZENER, G. and STANGARLIN, J.R., 2010. Damages caused by Bipolaris maydis in Panicum maximum cv. Tanzânia. Semina: Ciências Agrárias, vol. 31, no. 4, pp. 863-870. http:// dx.doi.org/10.5433/1679-0359.2010v31n4p863.

MILGROOM, M.G., LIPARI, S.E. and WANG, K., 1992. Comparison of genetic diversity in the chestnut blight fungus, Cryphonectria (Endothia) parasitica, from China and the US. Mycological Research, vol. 96, no. 12, pp. 1114-1120. http://dx.doi.org/10.1016/ S0953-7562(09)80123-8.

MISHRA, B., SINHA, B.K., JHA, M.M. and MISHRA, M.M., 1983. Seed mycoflora and nematode of maize and proso-millet in storage. Rajendra Agricultural University Journal of Research., vol. 4, no. 1-2, pp. 91-94.

MISRA, A.P. and SINGH, R.A., 1972. Comparative pathogenicity of different species of Helminthosporium on wheat in India. In: Proceedings of the 59th Indian Science Congress, 1972, Calcutta: Eureka meg.com. 567.

MUELLER, U.G., LIPARI, S.E. and MILGROOM, M.G., 1996. Amplified fragment length polymorphism (AFLP) fingerprinting of symbiotic fungi cultured by the fungus growing ant cyphomyrmex minutus. Molecular Ecology, vol. 5, no. 1, pp. 119-122. http://dx.doi.org/10.1111/j.1365-294X.1996.tb00297.x. PMid:9147688.

NEI, M. and LI, W.H., 1979. Mathematical model for studying genetic variation in terms of restriction endonucleases. Proceedings of the National Academy of Sciences of the United States of America, vol. 76, no. 10, pp. 5269-5273. http://dx.doi.org/10.1073/ pnas.76.10.5269. PMid:291943. 
NELSON, R.R. and KLINE, D.M., 1969. Occurrence in Cochliobolus heterostrophus of capacities to blight gramineous hosts. The Plant Disease Reporter, vol. 52, pp. 879-882.

OLIVEIRA, A.M.R., MATSUMURA, A.T.S., PRESTESI, A.M., MATOS, C.S. and SAND, S.T., 1998. Morphological variability and pathogenicity in isolates of Bipolaris sorokiniana. Fitopatologia Brasileira, vol. 33, no. 3, pp. 319-353.

PAL, I., SINGH, V.R., GOGOI, K., HOODA, K.S. and BEDI, N., 2015. Characterization of Bipolaris maydis isolates of different maize cropping zones of India. Indian Phytopathology, vol. 68, pp. 6366. http://dx.doi.org/10.13140/RG.2.2.24187.21281.

PEDERSEN, W.L. and OLDHAM, M.G., 1992. Effect of three tillage practices on development of northern corn leaf blight (Exserohilum turcicum) under continuous corn. Plant Disease, vol. 76, no. 11, pp. 1161-1164. http://dx.doi.org/10.1094/PD-76-1161.

PEEVER, T.L. and MILGROOM, M.G., 1994. Genetic structure of Pyrenophora teres populations determined with random amplified polymorphic DNA markers. Canadian Journal of Botany, vol. 72, no. 7, pp. 915-923. http://dx.doi.org/10.1139/b94-116.

RAEDER, U. and BRODA, P., 1985. Rapid preparation of DNA from filamentous fungi. Letters in Applied Microbiology, vol. 1, no. 1, pp. 17-20. http://dx.doi.org/10.1111/j.1472-765X.1985.tb01479.x.

REGUCHANDER, T., KULKARNI, S. and HEGDE, R.K., 1988. Cultural characteristics of a causal agent of leaf blight of triticale. Plant Pathology Newsletter, vol. 6, no. 1-2, pp. 43-44.

SHARMA, R., 1983. Techniques of scoring for resistance to important diseases of maize. New Delhi: Indian Agricultural Research Institute, pp. 1-4. All India coordinated Maize Improvement Project.
STANKOVIĆ, S., LEVIĆ, J. and IVANOVIĆ, D., 2007. Genetic variability of maize pathogens in Serbia. Genetika., vol. 39, no. 2, pp. $227-$ 240. http://dx.doi.org/10.2298/GENSR0702227S.

TAMURA, K. and NEI, M., 1993. Estimation of the number of nucleotide subsitutions in the control region of mitochondrial DNA in humans and vhimpanzez. Molecular Biology and Evolution, vol. 10, no. 3, pp. 512-526. PMid:8336541.

WANG, M., WANG, S., MA, J., YU, C., GAO, J. and CHEN, J., 2017. Detection of Cochliobolus heterostrophus races in South China. Journal of Phytopathology, vol. 165, no. 10, pp. 681-691. http:// dx.doi.org/10.1111/jph.12607.

WEEMS, J.D., 2016. Evaluation of race population distribution, fungicide sensitivity, and fungicide control of Exserohilum turcicum, the causal agent of northern leaf blight of corn. Champaign: University of Illinois at Urbana-Champaign.

WEIKERT-OLIVEIRA, R.C., RESENDE, M., VALÉRIO, H.M., CALIGIORNE, R.B. and PAIVA, E., 2002. Genetic variation among pathogens causing" Helminthosporium" diseases of rice, maize and wheat. Fitopatologia Brasileira, vol. 27, no. 6, pp. 639-643. http://dx.doi. org/10.1590/S0100-41582002000600015.

WETZEL 3RD, W.C., SKINNER, D.Z. and TISSERAT, N.A., 1999. Geographic distribution and genetic diversity of three Ophiosphaerella species that cause spring dead spot of Bermuda grass. Plant Disease, vol. 83, no. 12, pp. 1160-1166. http://dx.doi. org/10.1094/PDIS.1999.83.12.1160. PMid:30841143.

WISE, K. and MUELLER, D., 2011. Are fungicides no longer just for fungi? An analysis of foliar fungicide use in corn. St Paul: APS Membership. APSnet Features. 